\title{
Proteasome inhibitor MG132 inhibits the process of renal interstitial fibrosis
}

\author{
LIN HAN $^{1}$, BINGBING ZHU ${ }^{2}$, HUI CHEN ${ }^{2}$, YUANMENG JIN ${ }^{2}$, JIAN LIU ${ }^{2}$ and WEIMING WANG ${ }^{2}$ \\ ${ }^{1}$ Department of Nephrology, Yangpu Hospital, Tong Ji University, School of Medicine, Shanghai 200090; \\ ${ }^{2}$ Department of Nephrology, Ruijin Hospital, Shanghai Jiao Tong University, \\ School of Medicine, Shanghai 200025, P.R. China
}

Received May 5, 2018; Accepted December 13, 2018

DOI: $10.3892 /$ etm.2019.7329

\begin{abstract}
The proteasome inhibitor pathway serves a crucial role in cell cycle progression and apoptosis, and in the activation of transcription factors and cytokines in tumor cells. The aim of the current study was to investigate the effect of the proteasome inhibitor, MG132, on transforming growth factor (TGF)- $\beta 1$-induced expression of extracellular matrix proteins in rat renal interstitial fibroblasts (NRK-49F cells) and to better elucidate the mechanism by which MG132 functions. The level of connective tissue growth factor (CTGF), $\alpha$-smooth muscle actin (SMA), fibronectin (FN) and collagen type III (Col III) in the MG132-pretreated groups was significantly decreased compared with groups treated with TGF- $\beta 1$ alone. MG132 significantly decreased mRNA and the protein levels of fibrosis-associated factors induced by TGF- $\beta 1$ treatment. The MG132-pretreated groups exhibited lower phosphorylated-mothers against decapentaplegic homolog (p-Smad)2, p-Smad3 and FN protein expression compared with the groups treated with TGF- $\beta 1$ alone. In conclusion, MG132 reduced mRNA and protein expression of fibrosis-associated factors. It can successfully inhibit the inflammatory reaction induced by TGF- $\beta$ via the Smad signaling pathway. These results indicate that MG132 appears to have a potent effect in counteracting renal fibrosis. MG132 may be applied in the treatment of patients with chronic kidney disease.
\end{abstract}

\section{Introduction}

Renal interstitial fibrosis is the final common pathway of end stage renal disease (1). It is characterized by the increased deposition of extracellular matrix (ECM) materials, including

Correspondence to: Professor Weiming Wang, Department of Nephrology, Ruijin Hospital, Shanghai Jiao Tong University, School of Medicine, 197 Ruijin Second Road, Shanghai 200025, P.R. China E-mail:wwm11120@rjh.com.cn

Key words: proteasome inhibitor, renal interstitial fibroblast, transforming growth factor- $\beta 1$, extracellular matrix, mothers against decapentaplegic homolog collagen type I (Col I) and type III (Col III), fibronectin (FN), and laminin, as well as activated renal interstitial fibroblasts (2). Transforming growth factor (TGF)- $\beta 1$ is one of the main factors that can induce fibrosis (3). TGF- $\beta 1$ has been identified as a central mediator in renal fibrosis (4). TGF- $\beta$ initiates canonical and non-canonical pathways to exert multiple biological effects (5). Among them, the mothers against decapentaplegic homolog (Smad) signaling pathway has been recognized as a major pathway of TGF- $\beta$ signaling in progressive renal fibrosis (6). Connective tissue growth factor (CTGF) is one of the downstream factors that induce fibrosis (7). In a normal physiological environment, CTGF has been demonstrated to be mainly involved in angiogenesis and cell differentiation (8). It is worth noting that CTGF could mediate the process of tissue repair and fibrosis under pathological conditions (9). In the process of myocardial injury, repair and fibrosis, CTGF has been revealed to be a molecule that activates fibroblasts (10). The central link of renal interstitial fibrosis is the activation of fibroblasts with the expression of $\alpha$-smooth muscle actin (SMA) serving as the main biomarker (11). $\alpha$-SMA is a hallmark of a variety of renal phenotypic transformations and has been commonly used to detect the phenotypic transformation of fibroblasts into myofibroblasts (12). $\alpha$-SMA-positive myofibroblasts have been demonstrated to be the main synthetic cells that deposit ECM materials (12).

The amount of collagen secreted by myofibroblasts has been determined four to five times greater than that of fibroblasts; collagen has been revealed to increase the deposition of ECM (13). Furthermore, myofibroblasts have a strong contractile capacity, which has been demonstrated to cause the remodeling of the kidney structure, resulting in fibrosis (14). Smads are involved in the TGF- $\beta 1$ signal transduction pathway (15). It has been consistently demonstrated that Smad2 and Smad3 are extensively activated in the fibrotic kidney in patients with and animal models of chronic kidney disease (6). The phosphorylated (p-)Smad2 and p-Smad3 form an oligomeric complex with a common Smad, Smad4, which has been revealed to translocate into the nucleus to regulate the transcription of target genes in collaboration with various co-activators and co-repressors, ultimately inducing fibrosis (16). Proteasome inhibitors can interfere with and influence cellular functions by inhibiting the activity of the proteasome (17). Therefore, using a proteasome inhibitor 
to change the activity of the proteasome cleavage site is the focal point of studies on inflammation by our group (18). A previous study demonstrated that a proteasome inhibitor, MG132, inhibited proliferation and induced apoptosis in renal interstitial fibroblasts that had been stimulated to differentiate into myofibroblasts by TGF- $\beta 1$ (19). In the current study, the authors examined the influence of MG132 on TGF- $\beta 1$-induced renal interstitial fibrosis to investigate the potential application of MG132 in slowing renal interstitial fibrosis, as well as the potential mechanism by which it functions.

\section{Materials and methods}

Chemicals. TGF- $\beta 1$ was purchased from R\&D Systems, Inc. (Minneapolis, MN, USA). Dulbecco's modified Eagle's medium: Nutrient Mixture F-12 (DMEM/F12) cell culture medium and trypsin-EDTA were purchased from Gibco (Thermo Fisher Scientific, Inc., Waltham, MA, USA). Fetal calf serum (FCS) was purchased from PAA Laboratories (GE Healthcare, Chicago, IL, USA). The proteasome inhibitor, MG132, was purchased from Calbiochem (EMD Millipore, Billerica, MA, USA) and dissolved in dimethyl sulfoxide as a $40 \mu \mathrm{M}$ stock solution stored at $-20^{\circ} \mathrm{C}$. Reverse transcription associated reagents were purchased from Promega Corporation (Madison, WI, USA). Quantitative polymerase chain reaction (qPCR) primers were synthesized by Sangon Biotech Co., Ltd. (Shanghai, China). Rabbit anti-rat Smad2/3 (cat. no. 5678), p-Smad2 (cat. no. 3104), p-Smad3 (cat. no. 9520), $\alpha$-SMA (cat. no. \#19245) and GAPDH (cat. no. \#8884) monoclonal antibodies were obtained from Cell Signaling Technology, Inc. (Danvers, MA, USA). Rabbit anti-rat CTGF (cat. no. 555SR-100) monoclonal antibodies were obtained from BioVision, Inc. (Milpitas, CA, USA). Mouse anti-rat FN monoclonal antibodies (cat. no. AB2051) were purchased from EMD Millipore. Mouse anti-rat $\beta$-actin (cat. no. A1978) and rabbit anti-rat Col III (cat. no. SAB4200749) monoclonal antibodies were bought from Sigma-Aldrich (Merck KGaA, Darmstadt, Germany). Horseradish peroxidase (HRP)-conjugated immunoglobulin ( $\mathrm{Ig}) \mathrm{G}$ secondary antibodies (goat anti-rabbit, cat. no. 5220-0337; goat anti-mouse, cat. no. 5450-0011) were obtained from Kirkegaard \& Perry Laboratories (SeraCare Life Sciences Inc., Milford, MA, USA). Enhanced chemiluminescence reagent (Western lightning Plus-ECL; cat. no. NEL105001EA) was purchased from Edo Biotech AB (Lindome, Sweden) and polyvinylidene fluoride (PVDF) membranes were purchased from EMD Millipore.

Cell culture. Rat renal fibroblast NRK-49F cells (American Type Culture Collection, Manassas, VA, USA) were cultured in DMEM/F12 medium supplemented with $10 \%$ FCS in a humidified incubator containing $5 \% \mathrm{CO}_{2}$ at $37^{\circ} \mathrm{C}$.

Reverse transcription (RT)-qPCR analysis. Cells plated in 6 -well plates $\left(2 \times 10^{6} /\right.$ well $)$ were treated with TGF- $\beta 1(5 \mathrm{ng} / \mathrm{ml})$ with or without MG132 at specific concentrations $(0,0.5$, $1,2.5$ and $5 \mu \mathrm{M}$ ) for $24 \mathrm{~h}$. The control group was defined as untreated cells cultured for $24 \mathrm{~h}$. Another group of cells plated in 6 -well plates $\left(2 \times 10^{6} /\right.$ well $)$ were treated the cells with TGF- $\beta 1(5 \mathrm{ng} / \mathrm{ml})$ with or without MG132 $(2.5 \mu \mathrm{M})$ for defined lengths of time (0, 6, 12 and $24 \mathrm{~h})$. In this group, the control group was defined as cells cultured for $0 \mathrm{~h}$. RNA was purified using an RNA extraction kit (cat. no. Z3100; Promega Corporation), converted to cDNA using TaqMan ${ }^{\mathrm{TM}}$ microRNA RT kit (cat. no. 4366596; Thermo Fisher Scientific, Inc.) and the following genes were amplified: CTGF, $\alpha$-SMA, FN, Col III and GAPDH using the primers listed in Table I. SYBR Green reagent (Tokobo Ltd., London, UK) was used for PCR amplification and detection of transcripts. The reaction conditions were as follows: Denaturation at $94^{\circ} \mathrm{C}$ for $10 \mathrm{~min}$, and 40 cycles of denaturation at $94^{\circ} \mathrm{C}$ for $15 \mathrm{sec}$, and annealing and extension at $60^{\circ} \mathrm{C}$ for $1 \mathrm{~min}$. Each experiment was repeated three times in triplicate. Relative mRNA expression was calculated using the relative quantification method with GAPDH as an internal control (20). Data are expressed as n times the untreated group.

Treatment groups. The first collection of cells $\left(8 \times 10^{6}\right)$ were treated with TGF- $\beta 1(5 \mathrm{ng} / \mathrm{ml})$ for defined lengths of time $(0$, $6,12$ and $24 \mathrm{~h})$ with or without MG132 $(2.5 \mu \mathrm{M})$ pretreatment for $0.5 \mathrm{~h}$; the control group was defined as cells cultured for $0 \mathrm{~h}$. The second collection of cells were treated with TGF- $\beta 1$ $(5 \mathrm{ng} / \mathrm{ml})$ for $24 \mathrm{~h}$ with or without $0.5 \mathrm{~h}$ pretreatment with MG132 at $0.5,1,2.5$ and $5 \mu \mathrm{M}$. In these two collections, CTGF, $\alpha$-SMA, FN, Col III and GAPDH protein expression levels were assessed. The third collection of cells were treated with TGF- $\beta 1$ ( $5 \mathrm{ng} / \mathrm{ml})$ for different times $(0,15,30 \mathrm{~min}, 1$ and $2 \mathrm{~h})$; the control group was defined as cells cultured for $0 \mathrm{~min}$. The fourth collection of cells were treated with or without $0.5 \mathrm{~h}$ MG132 pretreatment at $0,0.5,1,2.5$ and $5 \mu \mathrm{M}$ and TGF- $\beta 1$ $(5 \mathrm{ng} / \mathrm{ml})$ treatment for $1 \mathrm{~h}$; the control group was defined as untreated cells cultured for $1 \mathrm{~h}$. In these two collections, p-Smad2, p-Smad3, Smad2/3 and $\beta$-actin protein expression levels were assessed. The fifth collection of cells were treated with TGF- $\beta 1(5 \mathrm{ng} / \mathrm{ml})$ with or without MG132 at $0.5,1,2.5$ and $5 \mu \mathrm{M}$ for $24 \mathrm{~h}$; the control group was defined as untreated cells cultured for $24 \mathrm{~h}$. FN and $\beta$-actin protein expression levels were assessed in this collection.

Western blotting. Following all treatments, cells were lysed in cell lysis solution (phenylmethylsulfonyl fluoride: Radioimmunoprecipitation assay, 1:100; cat. no. P0013B; Shanghai Biyuntian Bio-Technology Co., Ltd., Shanghai, China) at $4^{\circ} \mathrm{C}$ and centrifuged at $4,024 \mathrm{x}$ g for $30 \mathrm{~min}$ at $4^{\circ} \mathrm{C}$. Protein concentrations in the supernatant were determined using the Bradford method. Protein and loading buffer were mixed at a ratio of $4: 1$, boiled at $100^{\circ} \mathrm{C}$ for $5 \mathrm{~min}$ and then samples $(100 \mu \mathrm{g} / \mathrm{lane})$ were separated on $10 \%$ SDS-PAGE gels. Bands from the gels were transferred to PVDF membranes using $0.2 \mathrm{~A}$ and then blocked for $2 \mathrm{~h}$ at room temperature with 5\% skim milk in TBS/T buffer solution. Mouse anti-rat FN $(1: 1,000)$, mouse anti-rat $\beta$-actin (1:500), mouse anti-rat Col III $(1: 1,000)$ and rabbit anti-rat GPADH (1:1,000), CTGF (1:2,000), Smad2/3 (1:1,500), p-Smad2 and p-Smad3 monoclonal antibodies $(1: 5,000)$ were incubated overnight with the membranes at $4^{\circ} \mathrm{C}$. Membranes were then washed, and HRP-conjugated goat anti-mouse $\operatorname{IgG}(1: 2,000)$ or goat anti-rabbit $(1: 1,500)$ secondary antibodies were incubated with the membranes for $2 \mathrm{~h}$ at $4^{\circ} \mathrm{C}$. Membranes were then covered with ECL reagent in a darkroom for $5 \mathrm{~min}$ and exposed to X-ray film; the film was then developed and fixed. ImageJ software (version 1.8.0; National Institutes of Health, Bethesda, MD, USA) was used for the densitometric analysis of the blots. 
Table I. Primer sequences.

\begin{tabular}{llll}
\hline Gene & Type & Primer sequence (5'-3') & Product length (bp) \\
\hline GAPDH & Forward & AGTATGACTCCACTCACGGCAA & 100 \\
& Reverse & TCTCGCTCCTGGAAGATGGT & CATCCGACCTTGCTAACG \\
a-Smooth muscle actin & Forward & TCCAGAGTCCAGCACAATAC & 168 \\
Connective tissue growth factor & Reverse & ATCCCTGCGACCCACACAAG & 145 \\
& Forward & CAACTGCTTTGGAAGGACTCGC & 146 \\
Fibronectin & Reverse & CCAGGCACTGACTACAAGAT & 143 \\
& Forward & CATGATACCAGCAAGGAGT & \\
& Reverse & TGATGGGATCCAATGAGGGAGA & \\
\hline
\end{tabular}

Statistical analysis. All the data are expressed as mean \pm standard deviation, representative of three repeats and were analyzed by the SPSS 11.0 software package (SPSS, Inc., Chicago, IL, USA). Comparisons were made among groups using one-way analysis of variance followed by Fisher's Least Significant Difference test. $\mathrm{P}<0.05$ indicated that the difference between groups was statistically significant.

\section{Results}

MG132 downregulates the mRNA level of fibrosis-associated factors. NRK-49F cells have been demonstrated to express CTGF, $\alpha$-SMA, FN and Col III (6-9). Following treatment with different concentrations of MG132, the mRNA expression of CTGF, $\alpha$-SMA, FN and Col III decreased compared with the control group, and exhibited a potential dose-dependent effect (Fig. 1).

MG132 pretreatment decreases the mRNA level of fibrosis-associated factors in NRK-49F cells simulated by TGF- $\beta 1$ in a potential time-dependent manner. It was found that $2.5 \mu \mathrm{M}$ MG132 was effective in reducing the TGF- $\beta 1$-induced expression of fibrosis-associated genes (CTGF, $\alpha$-SMA, FN and Col III) at each time point assessed (6, 12 and 24 h; Fig. 2). Compared with the control group, CTGF mRNA levels in the TGF- $\beta 1$ group were 3.9-fold more greatly expressed at $6 \mathrm{~h}, 3.6$-fold higher at $12 \mathrm{~h}$, and 2.3-fold higher at $24 \mathrm{~h}$, indicating that the difference in expression gradually declined with increasing time following initial treatment. Following pretreatment with $2.5 \mu \mathrm{M}$ MG132, fold-changes decreased to 2.1, 1.8 and 1.4-fold for 6, 12 and $24 \mathrm{~h}$, respectively. The mRNA level of $\alpha$-SMA was also elevated after $6 \mathrm{~h}$ of TGF- $\beta 1$ stimulation. $\alpha$-SMA expression reached a peak at $12 \mathrm{~h}$ and was 26.2-fold more highly expressed compared the control group, but was only 10.9-fold higher at $24 \mathrm{~h}$. Compared with the control group, $\alpha$-SMA expression was significantly increased in after 6 and $12 \mathrm{~h}$ of TGF- $\beta 1$ stimulation (both $\mathrm{P}<0.05)$. Following pretreatment with $2.5 \mu \mathrm{M}$ MG132, these fold-changes in $\alpha$-SMA expression decreased to 4.2, 1.2 and 1.1 at 6,12 and $24 \mathrm{~h}$, respectively, of which $6 \mathrm{~h}$ of treatment increased expression significantly compared with the control group $(\mathrm{P}<0.05)$.

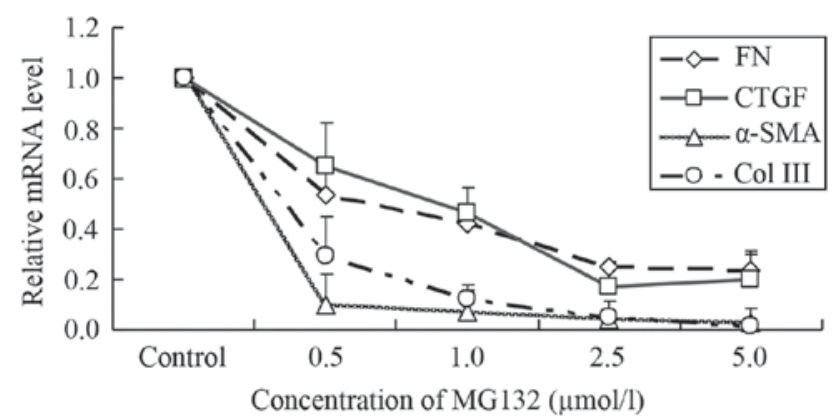

Figure 1. MG132 downregulates the mRNA level of fibrosis-associated factors. The mRNA levels were normalized to the control group. NRK-49F cells were treated with the proteasome inhibitor, MG132, at specific concentrations $(0-5 \mu \mathrm{M})$ for $24 \mathrm{~h}$. $\mathrm{P}<0.05$. Col III, collagen type III; FN, fibronectin; CTGF, connective tissue growth factor; $\alpha$-SMA, $\alpha$-smooth muscle actin.

The mRNA level of FN was 2.8-, 3.3- and 7.4-fold more highly expressed in TGF- $\beta 1$-treated cells at 6,12 and $24 \mathrm{~h}$, respectively, of which the $24 \mathrm{~h}$ stimulation was significantly increased compared with the control group $(\mathrm{P}<0.05)$. Following pretreatment with $2.5 \mu \mathrm{M}$ MG132, these values decreased to 1.9, 1.8 and 1.1-fold at 6, 12 and $24 \mathrm{~h}$, respectively. FN expression after $6 \mathrm{~h}$ of MG132 and TGF- $\beta 1$ treatment was significantly increased compared with the control group $(\mathrm{P}<0.05)$. The mRNA levels of Col III were 2.0, 2.5 and 2.8-fold higher in TGF- $\beta 1$-treated cells prior to pretreatment with MG132 and were reduced to $0.7,0.1$ and 0.1 -fold at 6,12 and $24 \mathrm{~h}$ after pretreatment, respectively. Col III expression was significantly increased $24 \mathrm{~h}$ after TGF- $\beta 1$ treatment and significantly decreased 6,12 and $24 \mathrm{~h}$ after MG132 and TGF- $\beta 1$ treatment compared with the control group (all $\mathrm{P}<0.05$ ). The results indicated that $2.5 \mu \mathrm{M}$ MG132 decreased the mRNA levels of fibrosis-associated factors following stimulation with $5 \mathrm{ng} / \mathrm{ml}$ TGF- $\beta 1$, which causes the fibroblasts to differentiate into myofibroblasts associated with fibrotic processes (21).

MG132 pre-treatment decreases on the mRNA level of fibrosis-associated factors in NRK-49F cells simulated by TGF- $\beta 1$ in a potential concentration-dependent manner. Cells pretreated with MG132 exhibited significant decreases in $\alpha$-SMA, CTGF, FN and Col III mRNA levels compared 

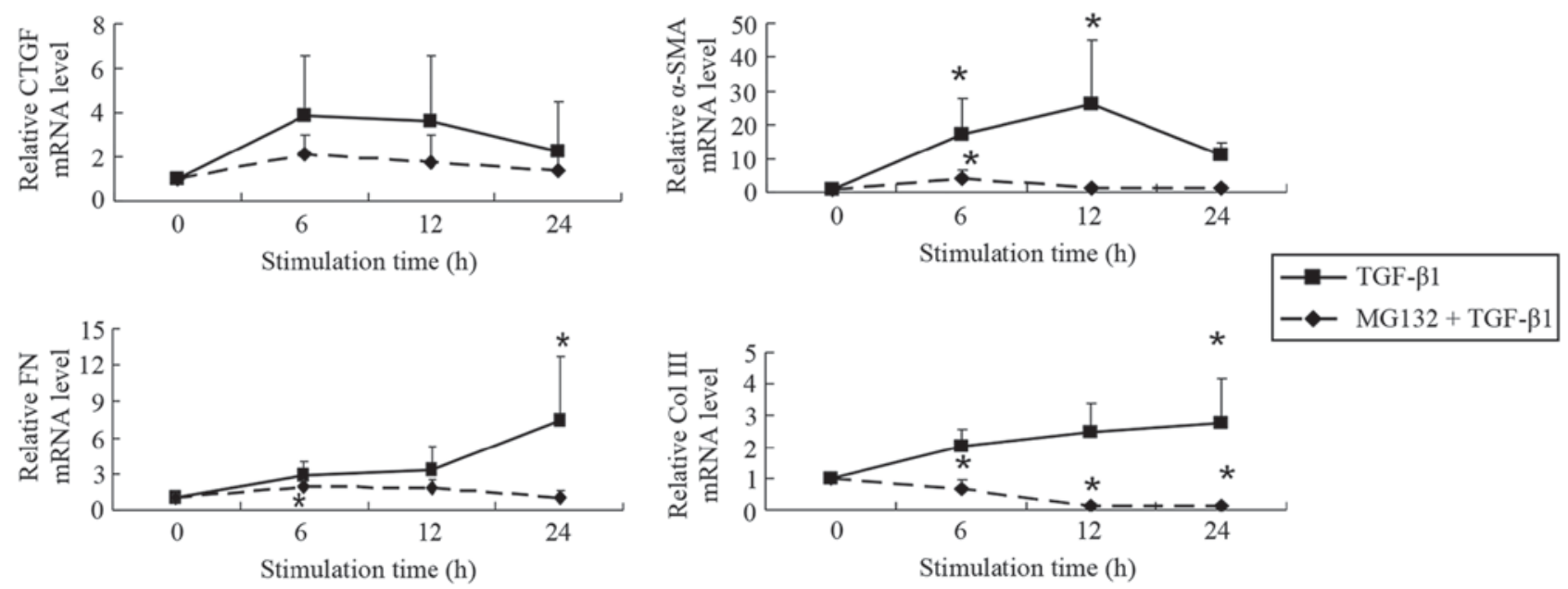

Figure 2. MG132 pretreatment decreases the mRNA level of fibrosis-associated factors in NRK-49F cells simulated by TGF- $\beta 1$ in what appears to be a time-dependent manner. The mRNA levels were normalized to the control group. NRK-49F cells were treated with TGF- $\beta 1$ (5 ng/ml) with or without MG132 $(2.5 \mu \mathrm{M})$ for designated lengths of time $(0-24 \mathrm{~h}) .{ }^{*} \mathrm{P}<0.05$ vs. the control group. Col III, collagen type III; FN, fibronectin; CTGF, connective tissue growth factor; $\alpha$-SMA, $\alpha$-smooth muscle actin; TGF, transforming growth factor.

with the TGF- $\beta 1$ group (P<0.05; Fig. 3). TGF- $\beta 1$ treatment significantly increased $\alpha$-SMA, CTGF, FN and Col III mRNA levels compared with the control group $(\mathrm{P}<0.05)$. $\alpha$-SMA mRNA levels significantly decreased in the presence of MG132 compared with the control group $(\mathrm{P}<0.05)$. TGF- $\beta 1$ mRNA levels significantly decreased with increasing MG132 concentration compared with the TGF- $\beta 1$ group $(\mathrm{P}<0.05)$; no significant changes were observed compared with the control group ( $\mathrm{P}>0.05)$. FN mRNA levels significantly decreased compared with the control group at 2.5 and $5 \mu \mathrm{M}$ MG132 (both $\mathrm{P}<0.05$ ). Col III mRNA levels significantly decreased with in the presence of MG132 compared with the control group $(\mathrm{P}<0.05)$. All mRNA levels exhibited a potential concentration-dependent manner.

MG132 pretreatment decreases the protein expression of fibrosis-associated factors in NRK-49F cells simulated by TGF- $\beta 1$ in a potential time-dependent manner. Compared with the control group set to $1, \mathrm{CTGF}$ expression was increased to 1.5 -fold at $6 \mathrm{~h}, 1.7$-fold at $12 \mathrm{~h}$ and 1.4 -fold at $24 \mathrm{~h}$ in the TGF- $\beta 1$ group; indicating that expression may declined over time following an initial increase (Fig. 4). In the group pretreated with MG132, CTGF expression of 1.4, 1.6 and 1.3-fold were measured at 6,12 and $24 \mathrm{~h}$, respectively. CTGF expression did not change significantly over time or between the TGF- $\beta 1$ and the MG132 pretreatment groups $(\mathrm{P}>0.05)$. Compared with the control group set to 1, $\alpha$-SMA protein levels increased to 2.6-fold at $6 \mathrm{~h}, 2.8$-fold at $12 \mathrm{~h}$ and 3.1-fold at $24 \mathrm{~h}$. Following pretreatment with $2.5 \mu \mathrm{M}$ MG132, these values were $1.3,1.7$ and 2.0 at 6,12 and $24 \mathrm{~h}$, respectively; differences between the TGF- $\beta 1$ and the pretreatment groups or over time were not significant $(\mathrm{P}>0.05)$. Protein levels of FN were determined at 2.3,3.5 and 5.8-fold TGF- $\beta 1$-treated cells at 6,12 and $24 \mathrm{~h}$, respectively, compared with the control group. The values determined at 12 and $24 \mathrm{~h}$ were significantly increased in the TGF- $\beta 1$ group compared with the $0 \mathrm{~h}$ control $(\mathrm{P}<0.05)$. After pre-treatment with MG132, FN protein expression values decreased to 1.8, 1.8 and 2.2-fold at 6,12 and $24 \mathrm{~h}$, respectively; differences over time or between the groups were not significant. Expression of Col III was 2.1,2.0 and 2.8-fold in the TGF- $\beta 1$ group at 6,12 and $24 \mathrm{~h}$, respectively and for the MG132 pretreatment group these values were 1.7, 1.8 and 1.8, respectively, compared with the $0 \mathrm{~h}$ control; differences between the groups were not significant. Col III protein expression was significantly increased at $24 \mathrm{~h}$ in the TGF- $\beta 1$ group compared with the $0 \mathrm{~h}$ control $(\mathrm{P}<0.05)$.

MG132 decreases the protein level of fibrosis-associated factors in NRK-49F cells simulated by TGF- $\beta 1$ in a potential concentration-dependent manner. Following pretreatment with $5 \mu \mathrm{M}$ MG132 and stimulation with $5 \mathrm{ng} / \mathrm{ml} \mathrm{TGF}-\beta 1$, the protein levels of CTGF, $\alpha$-SMA, FN and Col III were significantly decreased compared with the TGF- $\beta 1$ group $(\mathrm{P}<0.05$; Fig. 5). Compared with the TGF- $\beta 1$ group, the expression of CTGF decreased to 0.6-, 0.4-, 0.3- and 0.3-fold as the MG132 concentration increased to $0.5,1,2.5$ and $5 \mu \mathrm{M}$, respectively; of which changes at 1,2.5 and $5 \mu \mathrm{M}$ MG132 were significant (all $\mathrm{P}<0.05)$. The expression of $\alpha$-SMA decreased to 0.7-, 0.6-, 0.6and 0.5 -fold as the MG132 concentration increased to $0.5,1$, 2.5 and $5 \mu \mathrm{M}$, respectively, compared with the TGF- $\beta 1$ group; only the $5 \mu \mathrm{M}$ MG132 concentration significantly decreased $\alpha$-SMA expression $(\mathrm{P}<0.05)$. The expression of FN decreased to 0.5-, 0.5-, 0.3- and 0.2-fold, and Col III expression stagnated at 1.0, and decreased to 0.8-, 0.4- and 0.3-fold as the MG132 concentration increased to $0.5,1,2.5$ and $5 \mu \mathrm{M}$, respectively, compared with the TGF- $\beta 1$ group. Compared with the TGF- $\beta 1$ group, Col III expression was significantly decreased with 2.5 and $5 \mu \mathrm{M}$ MG132 (both $\mathrm{P}<0.05$ ).

TGF- $\beta 1$ increases on the phosphorylation of Smads. The results indicated that NRK-49F cells express the $\mathrm{p}-\mathrm{Smad} 2$, and p-Smad $3 \beta$ proteins (Fig. 6). After the cells were stimulated with TGF- $\beta 1$ for $15 \mathrm{~min}$, the expression of p-Smad 2 and $\mathrm{p}-\mathrm{Smad} 3$ increased, reaching their peak expression after $1 \mathrm{~h}$ of treatment, but decreasing after $2 \mathrm{~h}$. Compared with the control group, p-Smad3 levels were 1.8 -fold more greatly expressed at $15 \mathrm{~min}$, 3.6 -fold higher at $30 \mathrm{~min}, 4.6$-fold higher at $1 \mathrm{~h}$ and 2.7 -fold 

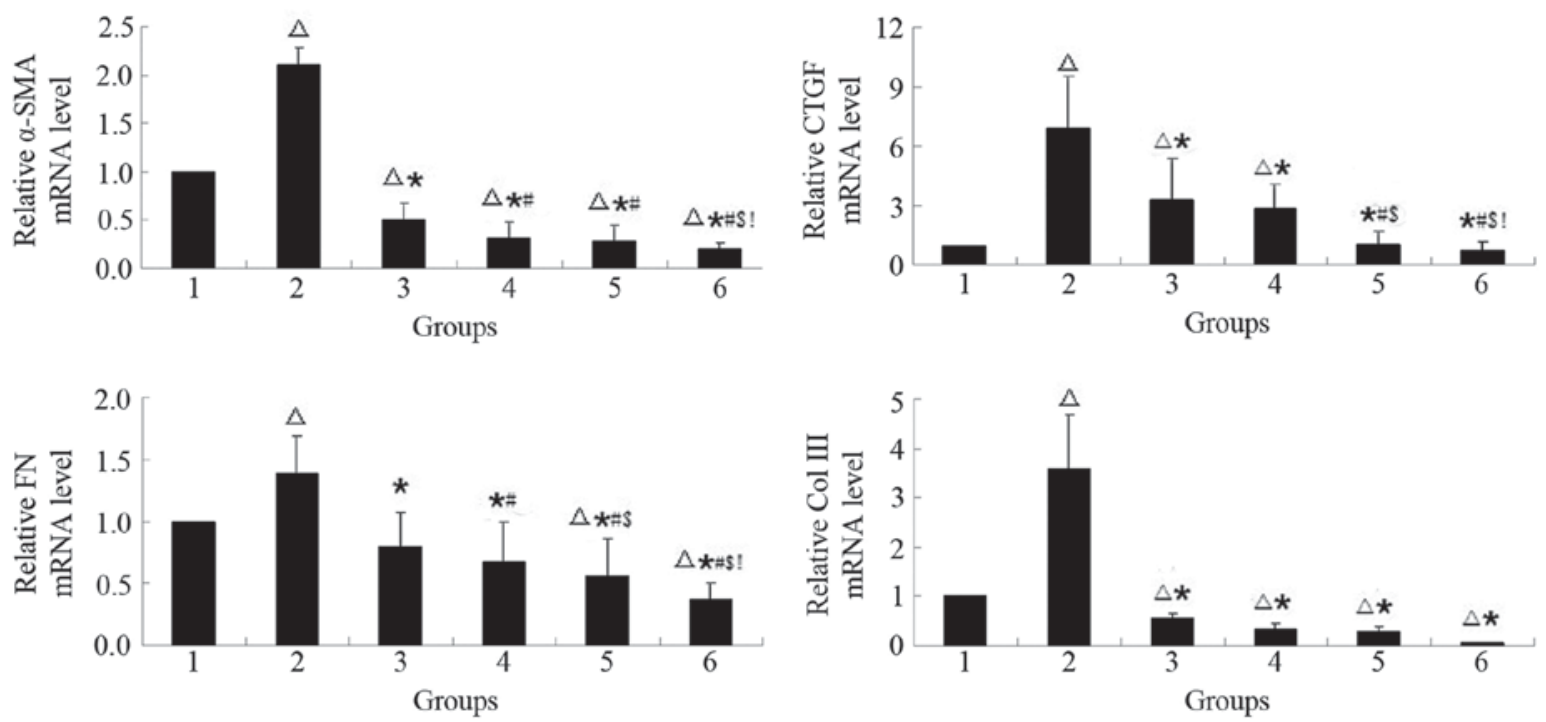

Figure 3. MG132 pre-treatment decreases on the mRNA level of fibrosis-associated factors in NRK-49F cells simulated by TGF- $\beta 1$ in a concentrationdependent manner. The mRNA levels were normalized to the control group. The cells were treated with the proteasome inhibitor, MG132, at specific concentrations $(0-5 \mu \mathrm{M})$ with or without TGF- $\beta 1(5 \mathrm{ng} / \mathrm{ml})$ for $24 \mathrm{~h} .{ }^{\Delta} \mathrm{P}<0.05$ vs. $1 ;{ }^{*} \mathrm{P}<0.05$ vs. $2 ;{ }^{~}{ }^{P} \mathrm{P}<0.05$ vs. $3 ;{ }^{\circledR} \mathrm{P}<0.05$ vs. 4 ; and ${ }^{~} \mathrm{P}<0.05$ vs. 5.1 , control; $2,5 \mathrm{ng} / \mathrm{ml}$ TGF- $\beta 1 ; 3,0.5 \mu \mathrm{M}$ MG132 + $5 \mathrm{ng} / \mathrm{ml}$ TGF- $\beta 1 ; 4,1 \mu \mathrm{M}$ MG132 + $5 \mathrm{ng} / \mathrm{ml}$ TGF- $\beta 1 ; 5,2.5 \mu \mathrm{M}$ MG132 + $5 \mathrm{ng} / \mathrm{ml}$ TGF- $\beta 1 ; 6,5 \mu \mathrm{M}$ MG132 + $5 \mathrm{ng} / \mathrm{ml}$ TGF- $\beta 1 ;$ Col III, collagen type III; FN, fibronectin; CTGF, connective tissue growth factor; $\alpha$-SMA, $\alpha$-smooth muscle actin; TGF, transforming growth factor.
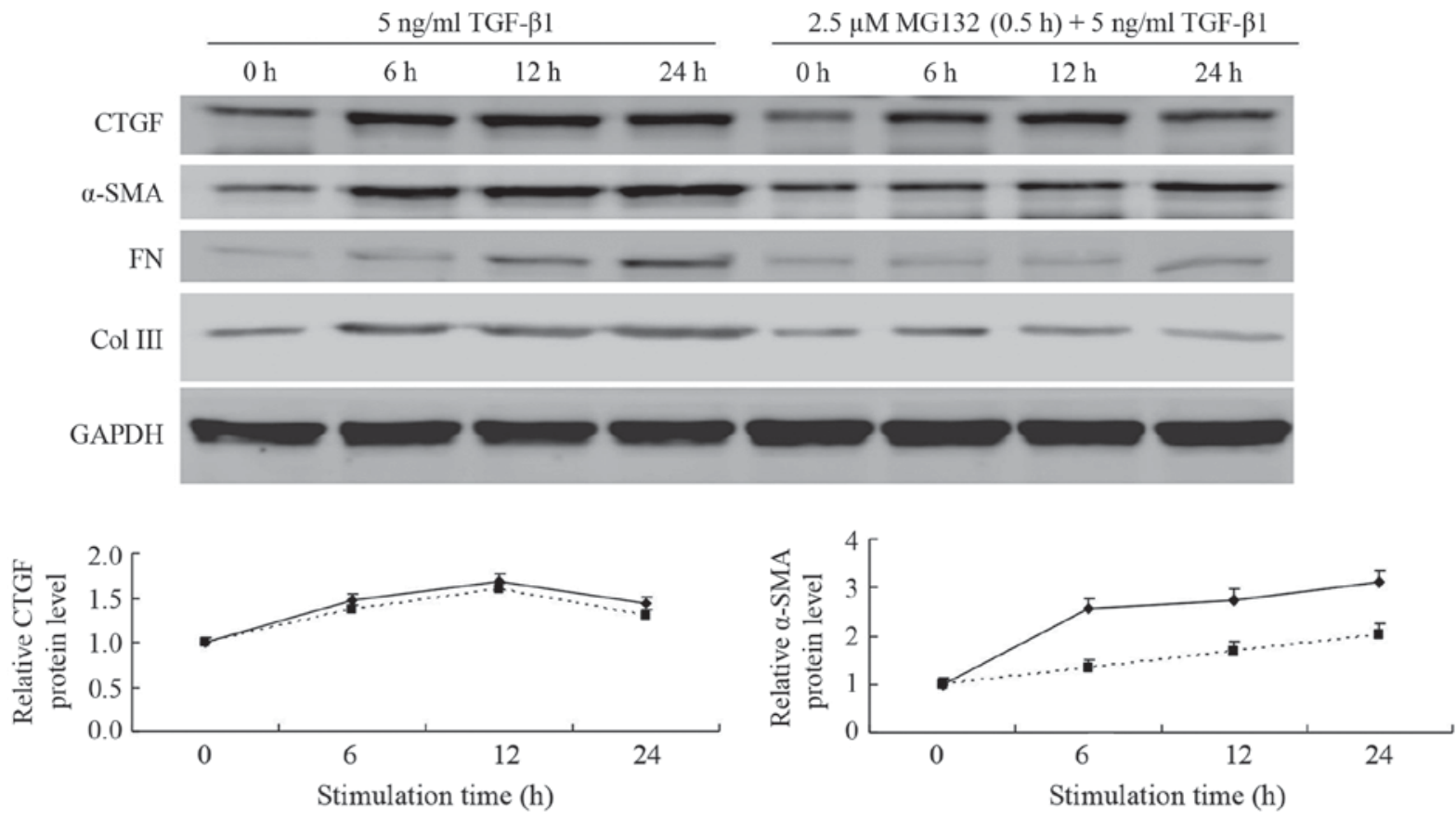

$\longrightarrow$ - TGF- $\beta 11$
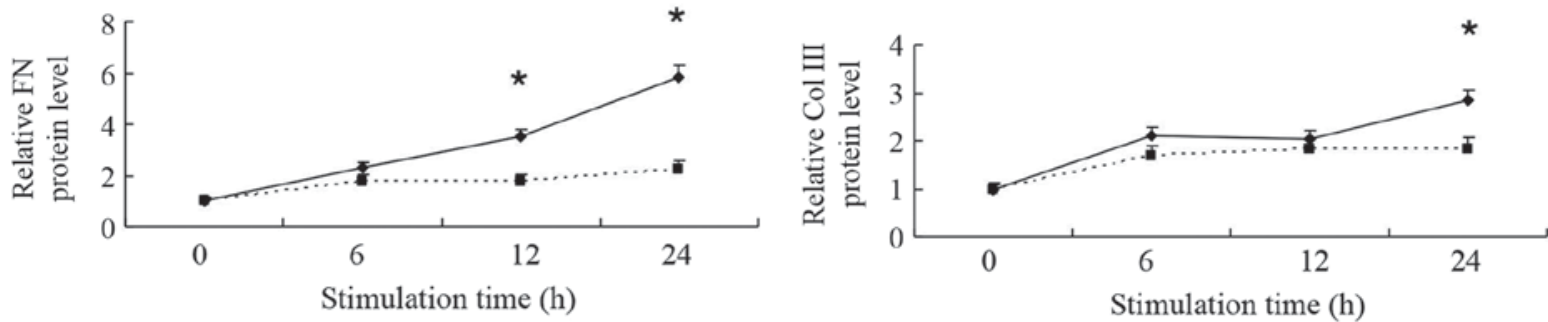

Figure 4. MG132 pretreatment decreases the protein expression of fibrosis-associated factors in NRK-49F cells simulated by TGF- $\beta 1$ in what appears to be a time-dependent manner. The protein levels were normalized to the control group. NRK-49F cells were treated with TGF- $\beta 1$ (5 ng/ml) with or without MG132 $(2.5 \mu \mathrm{M})$ for $0,6,12$ or $24 \mathrm{~h}$. "P<0.05 vs. the control group. Col III, collagen type III; FN, fibronectin; CTGF, connective tissue growth factor; $\alpha$-SMA, $\alpha$-smooth muscle actin; TGF, transforming growth factor. 

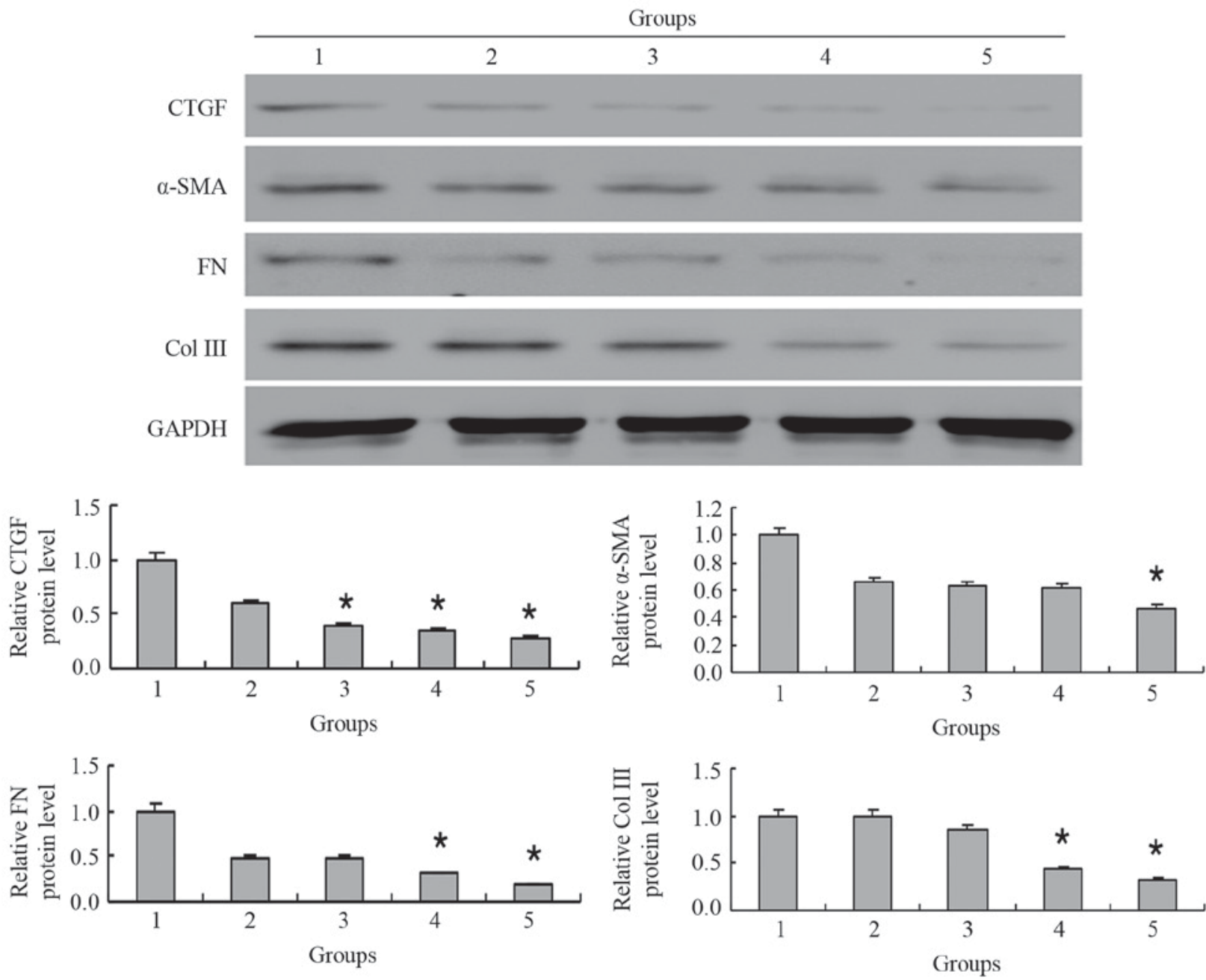

Figure 5. MG132 decreases the protein level of fibrosis-associated factors in NRK-49F cells simulated by TGF- $\beta 1$ in what appears to be a concentration-dependent manner. The protein levels were normalized to the control group. The cells were treated with the proteasome inhibitor, MG132, at specific concentrations $(0-5 \mu \mathrm{M})$ with TGF- $\beta 1$ (5 ng/ml) for $24 \mathrm{~h} .{ }^{*} \mathrm{P}<0.05$ vs. $2.1,5 \mathrm{ng} / \mathrm{ml}$ TGF- $\beta 1 ; 2,0.5 \mu \mathrm{M} \mathrm{MG132}+5 \mathrm{ng} / \mathrm{ml} \mathrm{TGF}-\beta 1 ; 3,1 \mu \mathrm{M} \mathrm{MG} 132+5 \mathrm{ng} / \mathrm{ml} \mathrm{TGF}-\beta 1 ; 4,2.5 \mu \mathrm{M}$ MG132 + $5 \mathrm{ng} / \mathrm{ml}$ TGF- $\beta 1 ; 5,5 \mu \mathrm{M}$ MG132 $+5 \mathrm{ng} / \mathrm{ml}$ TGF- $\beta 1$; Col III, collagen type III; FN, fibronectin; CTGF, connective tissue growth factor; $\alpha$-SMA, $\alpha$-smooth muscle actin; TGF, transforming growth factor.

higher at $2 \mathrm{~h}$. p-Smad3 levels were significantly increased after $30 \mathrm{~min}$ and $1 \mathrm{~h}$ of TGF- $\beta 1$ treatment compared with the control group (both $\mathrm{P}<0.05$ ). The levels of $\mathrm{p}$-Smad2 expression were 1.4-, 3.9-, 5.5- and 2.5-fold more highly expressed at 15 , $30 \mathrm{~min}, 1$ and $2 \mathrm{~h}$, respectively. p-Smad 2 levels were significantly increased after $15,30 \mathrm{~min}$ and $1 \mathrm{~h}$ of TGF- $\beta 1$ treatment compared with the control group (all $\mathrm{P}<0.05$ ).

MG132 decreases the phosphorylation of Smads in NRK-49F cells simulated by TGF- $\beta 1$. The results indicated that $5 \mathrm{ng} / \mathrm{ml}$ TGF- $\beta 1$ significantly increased the expression of $\mathrm{p}-\mathrm{Smad} 2$ and p-Smad3 compared with the control group $(\mathrm{P}<0.05$; Fig. 7$)$. After pretreatment with different concentrations of MG132 and then stimulation with $5 \mathrm{ng} / \mathrm{ml}$ TGF- $\beta 1$, the expression levels of $\mathrm{p}-\mathrm{Smad} 2$ and $\mathrm{p}-\mathrm{Smad} 3$ decreased. TGF- $\beta 1$ increased the p-Smad3 protein expression levels to 5.9-fold compared with the control group. This change was decreased to 4.6-, 4.2-, 3.0- and 2.6-fold as the MG132 concentration increased to $0.5,1,2.5$ and $5 \mu \mathrm{M}$, respectively, compared with the control group. p-Smad3 levels were significantly decreased with $1,2.5$ and $5 \mu \mathrm{M}$ MG132 pretreatments compared with the TGF- $\beta 1$ group (all $\mathrm{P}<0.05$ ). TGF- $\beta 1$ increased the $\mathrm{p}-\mathrm{Smad} 2$ levels to 1.2-fold compared with the control group. Compared with the control group, fold-changes decreased to 1.1-, 1.0-, 1.0- and 0.9 -fold, as the MG132 concentration increased to $0.5,1,2.5$ and $5 \mu \mathrm{M}$, respectively. p-Smad2 levels were significantly decreased with 2.5 and $5 \mu \mathrm{M}$ MG132 pretreatments compared with the TGF- $\beta 1$ group (both $\mathrm{P}<0.05$ ).

MG132 decreases the expression of FN in NRK-49F cells simulated by TGF- $\beta 1$. TGF- $\beta 1(5 \mathrm{ng} / \mathrm{ml})$ induced a significant, 11.9-fold increase in the FN protein expression levels compared with control group ( $\mathrm{P}<0.05$; Fig. 8). Fold-changes decreased to 8.0, 6.5,3.1 and 2.1-fold as the MG132 concentration increased to $0.5,1,2.5$ and $5 \mu \mathrm{M}$, respectively. FN levels decreased significantly compared with the control and TGF- $\beta 1$ groups, respectively (both $\mathrm{P}<0.05$ ).

\section{Discussion}

Renal interstitial fibroblasts are a subtype of renal interstitium intrinsic cells, which constitute the main ECM-secreting cell 

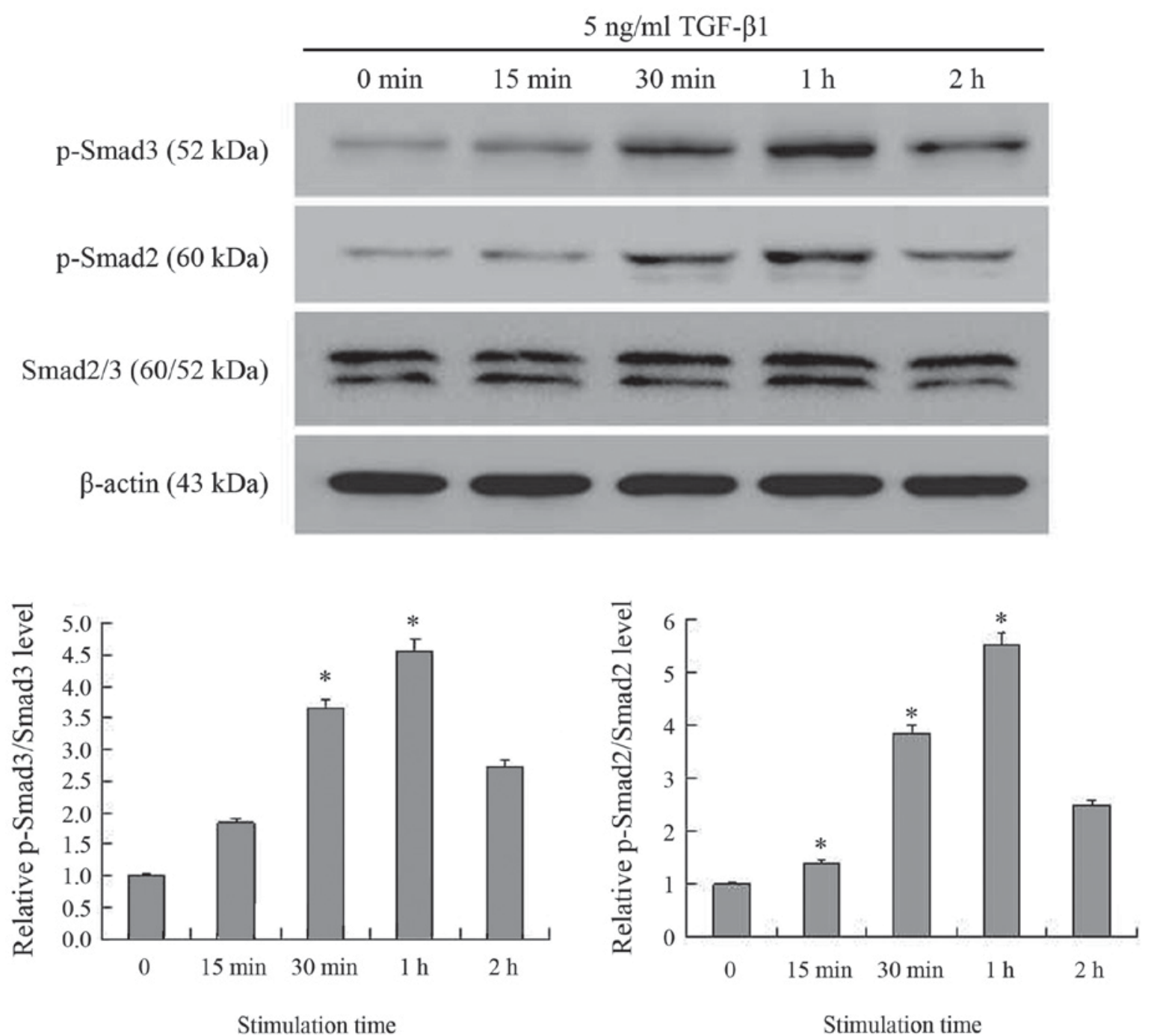

Figure 6. TGF- $\beta 1$ increases on the phosphorylation of Smads. The protein levels were normalized to the control group. NRK-49F cells were treated with $5 \mathrm{ng} / \mathrm{ml}$ TGF- $\beta 1$ for $0-120 \mathrm{~min}$. "P<0.05 vs. the control group. The experiments were repeated three times. TGF, transforming growth factor; $\mathrm{p}-$, phosphorylated; Smad, mothers against decapentaplegic homolog.

type during fibrosis (22). Due to their ability to proliferate quickly, interstitial fibroblasts can produce copious amounts of FN and collagen, specifically Col I and Col III (23). These cells serve a very important role in renal interstitial fibrosis, overproducing ECM materials that lead to scarring and fibrosis (24). Therefore, the authors of the current study monitored the expression of ECM materials and the signal transduction pathways regulating their production when renal interstitial fibroblasts were stimulated with pro-inflammatory signals (e.g. TGF- $\beta 1$ ). TGF- $\beta 1$ is closely connected with renal interstitial fibrosis, as it promotes the production of ECM materials (Col I, III and IV, and FN), while decreasing the expression of matrix metalloproteinases, thereby increasing the generation of plasminogen activator inhibitor and tissue inhibitor of metalloproteinases, which altogether slow ECM degradation (25). When the TGF- $\beta 1$ signal is transduced, it connects with TGF- $\beta 1$ receptor I and II, causing phosphorylation of the signal transduction factors, Smad2 and Smad3; these factors translocate to the cell nucleus with Smad4 to initiate the transcription of genes involved in fibrosis, cell proliferation and inflammation (26). The Smad signaling pathway has been implicated in several renal diseases and pathophysiologic reactions, including diabetic nephropathy, glomerular nephritis and glomerular sclerosis (27).

CTGF is an important downstream effector of TGF- $\beta 1$ (28). It has been demonstrated to promote TGF- $\beta 1$-induced cell proliferation and ECM deposition, inducing conglutination and chemotactic effects, while promoting epithelial to mesenchymal transition (29). Several in vitro studies have determined that CTGF stimulates the proliferation of cardiac fibroblasts and increase the production of the ECM $(30,31)$. Resulting myofibroblasts and tubular epithelial cells have been revealed to produce ECM materials to induce interstitial fibrosis (32). $\alpha$-SMA is a phenotypic transformation marker that is highly expressed in myofibroblasts, which are widely used as a marker of cell differentiation, while its production simultaneously contributes significantly to fibrosis (33).

Activation of the ubiquitin-proteasome pathway has been demonstrated to lead to the selective degradation of intracellular proteins and to the regulation of their degradation (34). By controlling the concentration of intracellular proteins, cells can maintain their internal environment (35). Key 

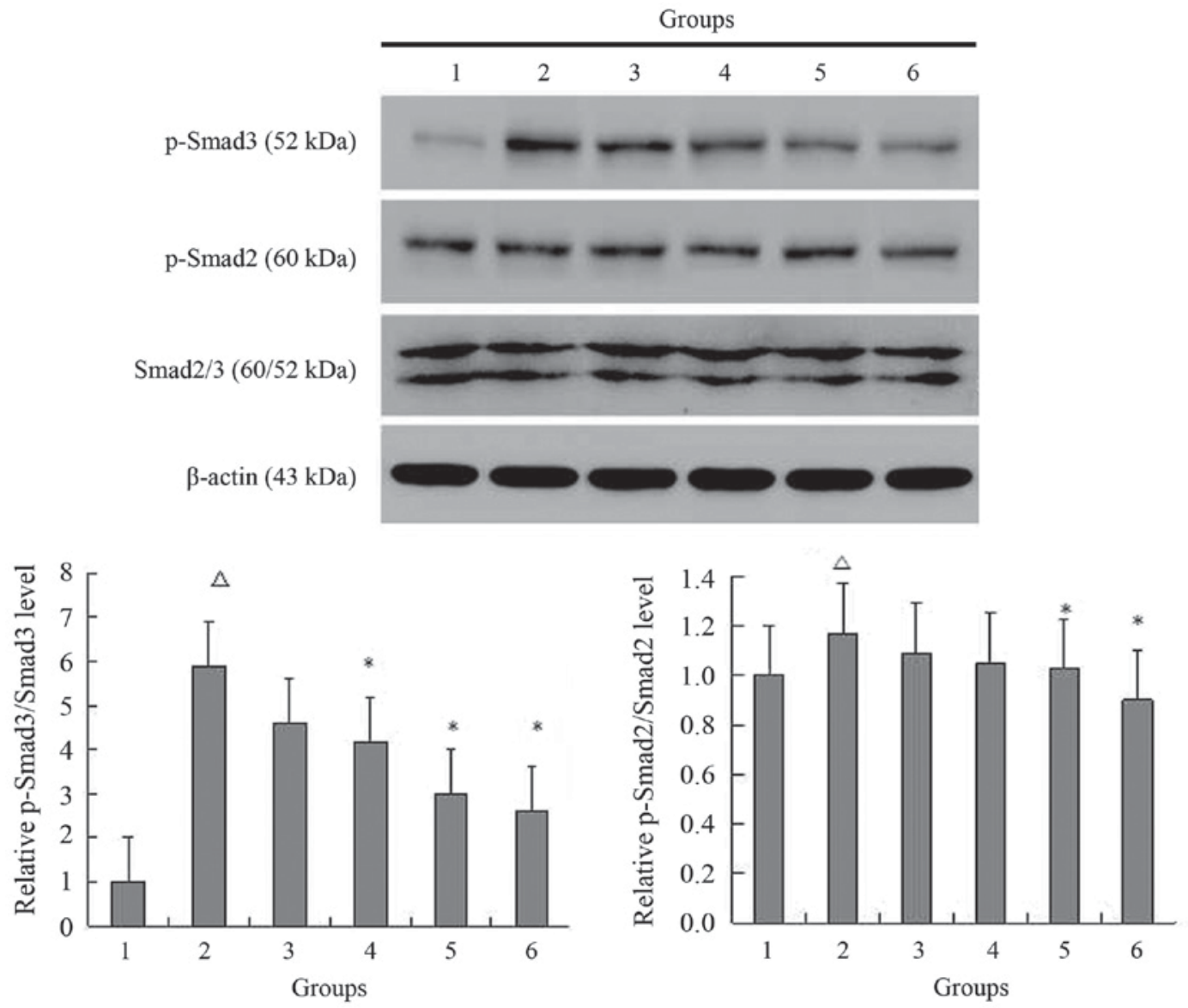

Figure 7. MG132 decreases the phosphorylation of Smads in NRK-49F cells simulated by TGF- $\beta 1$. The protein levels were normalized to the control group. The cells were treated with the proteasome inhibitor MG132 at specific concentrations $(0-5 \mu \mathrm{M})$ with or without TGF- $\beta 1$ ( $5 \mathrm{ng} / \mathrm{ml})$ for $1 \mathrm{~h}$. ${ }^{*} \mathrm{P}<0.05 \mathrm{vs} .2$; ${ }^{\Delta} \mathrm{P}<0.05$ vs. 1 . The experiments were repeated three times. 1 , control; $2,5 \mathrm{ng} / \mathrm{ml} \mathrm{TGF}-\beta 1 ; 3,0.5 \mu \mathrm{M} \mathrm{MG} 132+5 \mathrm{ng} / \mathrm{ml} \mathrm{TGF}-\beta 1 ; 4,1 \mu \mathrm{M} \mathrm{MG132}+5 \mathrm{ng} / \mathrm{ml}$ TGF- $\beta 1 ; 5,2.5 \mu \mathrm{M}$ MG132 + $5 \mathrm{ng} / \mathrm{ml}$ TGF- $\beta 1 ; 6,5 \mu \mathrm{M}$ MG132 + $5 \mathrm{ng} / \mathrm{ml}$ TGF- $\beta 1$; TGF, transforming growth factor; p-, phosphorylated; Smad, mothers against decapentaplegic homolog.

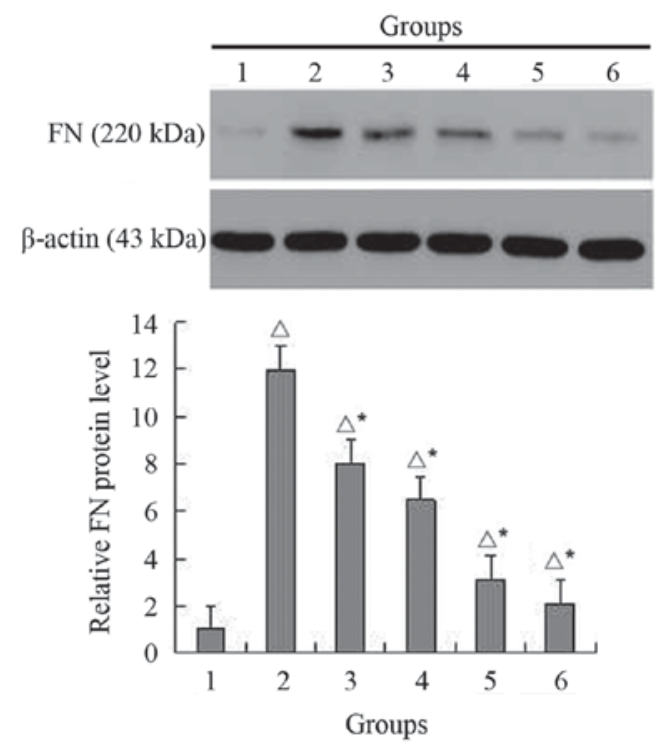

Figure 8. MG132 decreases the expression of FN in NRK-49F cells simulated by TGF- $\beta 1$. The protein levels were normalized to the control group. The cells were treated with the proteasome inhibitor MG132 at specific concentrations $(0-5 \mu \mathrm{M})$ with or without TGF- $\beta 1(5 \mathrm{ng} / \mathrm{ml})$ for $24 \mathrm{~h}$. ${ }^{*} \mathrm{P}<0.05$ vs. $2 ;{ }^{\wedge} \mathrm{P}<0.05$ vs. 1 . The experiments were repeated three times. 1 , control; 2, $5 \mathrm{ng} / \mathrm{ml}$ TGF- $\beta 1 ; 3,0.5 \mu \mathrm{M}$ MG132 $+5 \mathrm{ng} / \mathrm{ml}$ TGF- $\beta 1 ; 4,1 \mu \mathrm{M}$ $\mathrm{MG} 132+5 \mathrm{ng} / \mathrm{ml}$ TGF- $\beta 1 ; 5,2.5 \mu \mathrm{M}$ MG132 $+5 \mathrm{ng} / \mathrm{ml} \mathrm{TGF}-\beta 1 ; 6,5 \mu \mathrm{M}$ MG132 + $5 \mathrm{ng} / \mathrm{ml}$ TGF- $\beta 1$. TGF, transforming growth factor; FN, fibronectin. proteins in this pathway include those that control inflammation and the cell cycle (36). Therefore, proteasome inhibitors have potential therapeutic applications in limiting inflammation and tumor growth (37). Clinical have demonstrated that Bortezomib (the first proteasome inhibitor drug) can induce the apoptosis of several haemal and solid tumors, including multiple myeloma, mantle cell lymphoma, non-small cell lung carcinoma, oophoroma, carcinoma of the pancreas, carcinoma of the prostate, and head and neck neoplasms (38). Proteasome inhibitors have been adopted in pilot studies involving antibody-mediated renal rejection in amyloid light chain amyloidosis with increasing scientific interest in their possible applications in lupus, IgA nephropathy, idiopathic nephrotic syndrome and renal fibrosis therapies $(39,40)$. The ubiquitin-proteasome inhibitor, MG132, is a specific inhibitor that directly affects uridine phosphorylase (UPP) (41). When UPP is inhibited, the degradation of intracellular abnormal proteins, such as caspase 3 , reduces (42). Activated caspase 3 decomposes substrates in the cytoplasm and nucleus, resulting in chromosome condensation, mitochondrial swelling and ultimately apoptosis (43). Caspase 3 can thereby reduce extracellular matrix secretion through the lysis of cells involved in its generation (44). Studies have revealed that MG132 can inhibit alimentary canal neoplasms and leukemia (45-47). 
The authors of the current study used TGF- $\beta 1$ to induce myofibroblast transformation in NRK-49F cells and observed that $\mathrm{p}-\mathrm{Smad} 2$ and $\mathrm{p}-\mathrm{Smad} 3$ protein expression increased; these proteins have been known to promote the signal transduction pathways involved in fibrosis. It was demonstrated that MG132 can decrease the effects of TGF- $\beta 1$ by reducing the transcription of key factors involved in fibrosis, including CTGF, $\alpha$-SMA, FN and Col III.

During the TGF- $\beta 1$ signal transduction process, there are no known proteins that readily switch off transcription (48). Therefore, inhibiting proteins involved in the TGF- $\beta 1$ signaling pathway (e.g. Smad2, 3 and 4) is a plausible approach to limiting fibrosis (49). Another possible target would be the down-regulation of the Smad7 protein, which can lead to the inhibition of receptor-activated Smad-Smad4-complex activity, preventing the signal from progressing, thereby also decreasing or slowing the fibrotic process (50).

Ultimately, proteasome inhibitors possess some efficacy in delaying or impeding the process of renal interstitial fibrosis. They can promote cell apoptosis while down-regulating cytokine production, inflammation and the deposition of ECM materials, which has been determined to contribute to fibrosis (51). Therefore, the application of proteasome inhibitors in the treatment of fibrosis may be widely beneficial.

\section{Acknowledgements}

Not applicable.

\section{Funding}

The present study was supported by grants from the National Natural Science Foundation of China (grant nos. 30270613 and 30771000).

\section{Availability of data and materials}

The datasets used and/or analyzed during the current study are available from the corresponding author on reasonable request.

\section{Authors' contributions}

LH served an important role in interpreting the results, and drafting and writing the manuscript. LH, HC and JL performed experiments. BZ and YJ performed the statistical analyses of the data. WW was involved in drafting and reviewing the manuscript and contributed to the analysis and interpretation of data. All authors read and approved the final version of the manuscript.

\section{Ethics approval and consent to participate}

Not applicable.

\section{Patient consent for publication}

Not applicable.

\section{Competing interests}

The authors declare that they have no competing interests.

\section{References}

1. Liu M, Ning X, Li R, Yang Z, Yang X, Sun S and Qian Q: Signalling pathways involved in hypoxia-induced renal fibrosis. J Cell Mol Med 21: 1248-1259, 2017.

2. Vega G, Alarcon S and San Martin R: The cellular and signalling alterations conducted by TGF-nalling competino renal fibrosis. Cytokine 12: 115-125, 2016.

3. Meng XM and Lan HY: Transforming growth factor- $\beta$ and renal fibrosis. Sheng Li Xue Bao 70: 612-622, 2018 (In Chinese).

4. Xu J, Yu TT, Zhang K, Li M, Shi HJ, Meng XJ, Zhu LS and Zhu LK: HGF alleviates renal interstitial fibrosis via inhibiting the TGF- $\beta 1 /$ SMAD pathway. Eur Rev Med Pharmacol Sci 22: 7621-7627, 2018.

5. Soleimani A, Pashirzad M, Avan A, Ferns GA, Khazaei M and Hassanian SM: Role of the transforming growth factor- $\beta$ signaling pathway in the pathogenesis of colorectal cancer. J Cell Biochem 16: 2018.

6. Liu P, Zhu L, Zou G and Ke H: Matrine suppresses pancreatic fibrosis by regulating TGF- $\beta / \mathrm{Smad}$ signaling in rats. Yonsei Med J 60: 79-87, 2019.

7. Chen W, Zhou ZQ, Ren YQ, Zhang L, Sun LN, Man YL and Wang ZK: Effects of long non-coding RNA LINC00667 on renal tubular epithelial cell proliferation, apoptosis and renal fibrosis via the miR-19b-3p/LINC00667/CTGF signaling pathway in chronic renal failure. Cell Signal 54: 102-114, 2019.

8. Shieh JM, Tsai YJ, Chi JC and Wu WB: TGF $\beta$ mediates collagen production in human CRSsNP nasal mucosa-derived fibroblasts through Smad2/3-dependent pathway and CTGF induction and secretion. J Cell Physiol 13: 2018.

9. Balah A, Ezzat $O$ and Akool ES: Vitamin E inhibits cyclosporin A-induced CTGF and TIMP-1 expression by repressing ROS-mediated activation of TGF- $\beta /$ Smad signaling pathway in rat liver. Int Immunopharmacol 65: 493-502, 2018.

10. Chen L, Ji Q, Zhu H, Ren Y, Fan Z and Tian N: MiR-30a attenuates cardiac fibrosis in rats with myocardial infarction by inhibiting CTGF. Exp Ther Med 15: 4318-4324, 2018.

11. Chen M, Yan T, Ma K, Lai L, Liu C, Liang L and Fu X: Botulinum toxin type $\mathrm{A}$ inhibits $\alpha$-smooth muscle actin and myosin II expression in fibroblasts derived from scar contracture. Ann Plast Surg 77: 46-49, 2016.

12. Holm Nielsen S, Willumsen N, Leeming DJ, Daniels SJ, Brix S, Karsdal MA, Genovese F and Nielsen MJ: Serological assessment of activated fibroblasts by alpha-smooth muscle actin $(\alpha-$ SMA): A noninvasive biomarker of activated fibroblasts in lung disorders. Transl Oncol 12: 368-374, 2018.

13. Masola V, Bellin G, Gambaro G and Onisto M: Heparanase: A multitasking protein involved in extracellular matrix (ECM) remodeling and intracellular events. Cells 7: e236, 2018.

14. Meng XM, Tang PM, Li J and Lan HY: TGF- $\beta /$ Smad signaling in renal fibrosis. Front Physiol 6: 8, 2015.

15. Casas-Grajales S, Alvarez-Suarez D, Ramos-Tovar E, Dayana Buendía-Montaño L, Reyes-Gordillo K, Camacho J, Tsutsumi V and Lakshman MR: Stevioside inhibits experimental fibrosis by down-regulating profibrotic Smad pathways and blocking HSC activation. Basic Clin Pharmacol Toxicol 12: 123-126, 2018

16. Sakairi T, Hiromura K, Takahashi S, Hamatani H, Takeuchi S, Tomioka M, Maeshima A, Kuroiwa T and Nojima Y: Effects of proteasome inhibitors on rat renal fibrosis in vitro and in vivo. Neprology (Carlton) 16: 76-86, 2011.

17. Costa AR, Machado N, Rego A, Sousa MJ, Côrte-Real M and Chaves SR: Proteasome inhibition prevents cell death induced by the chemotherapeutic agent cisplatin downstream of DNA damage. DNA Repair (Amst) 73: 28-33, 2019.

18. van de Donk NWCJ and Yong K: Oral proteasome inhibitor maintenance for multiple myeloma. Lancet 393: 204-205, 2019.

19. Zhu B, Jin Y, Han L, Chen H, Zhong F, Wang W and Chen N: Proteasome inhibitor inhibits proliferation and induces apoptosis in renal interstitial fibroblasts. Phamacol Rep 65: 1357-1365, 2013.

20. Arocho A, Chen B, Ladanyi M and Pan Q: Validation of the 2-DeltaDeltaCt calculation as an alternate method of data analysis for quantitative PCR of BCR-ABL P210 transcripts. Diagn Mol Pathol 15: 56-61, 2006. 
21. Johnston EF and Gillis TE: Transforming growth factor- $\beta 1$ induces differentiation of rainbow trout (Oncorhynchus mykiss) cardiac fibroblasts into myofibroblasts. J Exp Biol 17: 221, 2018.

22. Waasdorp M, de Rooij DM, Florquin S, Duitman J and Spek CA Protease-activated receptor-1 contributes to renal injury and interstitial fibrosis during chronic obstructive nephropathy. J Cell Mol Med 23: 1268-1279, 2019.

23. Wang C, Luo H, Xu Y, Tao L, Chang C and Shen X: Salvianolic acid $\mathrm{B}$-alleviated angiotensin II induces cardiac fibrosis by suppressing NF- $\kappa \mathrm{B}$ pathway in vitro. Med Sci Monit 24 7654-7664, 2018.

24. Shao S, Zhang X, Duan L, Fang H, Rao S, Liu W, Guo B and Zhang X: Lysyl hydroxylase inhibition by minoxidil blocks collagen deposition and prevents pulmonary fibrosis via TGF- $\beta 1 / \mathrm{Smad} 3$ signaling pathway. Med Sci Monit 24: 8592-8601, 2018.

25. Meng XM, Nikolic-Paterson DJ and Lan HY: TGF- $\beta$ : The master regulator of fibrosis. Nat Rev Nephrol 12: 325-338, 2016.

26. Kothapalli D and Grotendorst GR: CTGF modulates cell cycle progression in cAMP-arrested NRK fibroblasts.J Cell Physiol 182: 119-126, 2000

27. Wang W, Koka V and Lan HY: Transforming growth factor-beta and Smad signaling in kidney diseases. Nephrology (Carlton) 10: 48-56, 2005

28. Zhu Y, Zhou J and Tao G: Molecular aspects of chronic radiation enterits. Clin Invest Med 34: E119-E124, 2011.

29. Xie Y, Ostriker AC, Jin Y, Hu H, Sizer AJ, Peng G, Morris AH, Ryu C, Herzog EL, Kyriakides T, et al: MO7 is a negative feedback regulator of TGF- $\beta$ signaling and fibrosis. Circulation 10 : $121-125,2018$

30. Petrosino JM, Leask A and Accornero F: Genetic manipulation of CCN2/CTGF unveils cell-specific ECM-remodeling effects in injured skeletal muscle. FASEB J 14: 2018.

31. Feng Jian, Zuo Yumei, Xu Liang, et al: Study of oleanolic acid in inhibiting rat cardiac fibroblasts proliferation induced by angiotensin II through ROS-CTGF pathway. Zhong Yao Xin Yao Yu Lin Chuang Bing Li 5: 78-82, 2014 (In Chinese).

32. Park J, Choi G, Yim MJ, Lee JM, Yoo JS, Park WS, Park SK, Park S, Seo SK, Kim TG, et al: Effect of phlorotannins on myofibroblast differentiation and ECM protein expression in transforming growth factor $\beta 1$ induced nasal polypderived fibroblasts. Int J Mol Med 42: 2213-2220, 2018.

33. Kalekou H, Kostopoulos I, Milias S and Papadimitriou CS: Comparative study of CD34, alpha-SMA and h-caldesmon expression in the stroma of gynaecomastia and male breast carcinoma. Histopathology 47: 74-81, 2005

34. Huang X, Wei S, Ni S, Huang Y and Qin Q: Ubiquitin-proteasome system is required for efficient replication of singapore grouper iridovirus. Front Microbiol 26: 2798, 2018.

35. Delpire E and Gagnon KB: Water homeostasis and cell volume maintenance and regulation. Curr Top Membr 81: 3-52, 2018

36. Della Sala G, Agriesti F, Mazzoccoli C, Tataranni T, Costantino V and Piccoli C: Clogging the ubiquitin-proteasome machinery with marine natural products: Last decade update. Mar Drugs 16 : E467, 2018.

37. Wang W, Luo J, Sheng W, Xue J, Li M, Ji J, Liu P, Zhang X, Cao $J$ and Zhang S: Proteomic profiling of radiation-induced skin fibrosis in rats: Targeting the ubiquitin-proteasome system. Int J Radiat Oncol Biol Phys 95: 751-760, 2016.

38. Wang M, Cai X, Yang J, Wang C, Tong L, Xiao J and Li L: A targeted and pH-responsive bortezomib nanomedicine in the treatment of metastatic bone tumors. ACS Appl Mater Interfaces 19: 2018.
39. Coppo R: Proteasome inhibitors in progressive renal diseases. Nephrol Dial Transplant 29 (Suppl 1): i25-i30, 2014.

40. Oliva L, Orfanelli U, Resnati M, Raimondi A, Orsi A, Milan E, Palladini G, Milani P, Cerruti F, Cascio P, et al: The amyloidogenic light chain is a stressor that sensitizes plasma cells to proteasome inhibitor toxicity. Blood 129: 2132-2142, 2017.

41. Luo D, Dong XW, Yan B, Liu M, Xue TH, Liu H, You JH, Li F, Wang ZL and Chen ZN: MG132 selectively upregulates MICB through the DNA damage response pathway in A549 cells. Mol Med Rep 20: 2018.

42. Luo DW, Zheng Z, Wang H, Fan Y, Chen F, Sun Y, Wang WJ, Sun $T$ and Xu X: UPP mediated diabetic retinopathy via ROS/PARP and NF- $\mathrm{BB}$ inflammatory factor pathways. Curr Mol Med 15: 790-799, 2015.

43. Cogo F, Poreba M, Rut W, Groborz K, Smyth P, Johnston MC, Williams R, Longley DB, Burden RE, Salvesen GS, et al: Development of an advanced nanoformulation for the intracellular delivery of a caspase-3 selective activity-based probe. Nanoscale 11: 742-751, 2019.

44. Zhao C, Qiu L, Lv P Han A, Fang G, Liu J and Wang S: AuNP-peptide probe for caspase-3 detection in living cells by SERS. Analyst 14: 2018.

45. Ortiz-Lazareno PC, Bravo-Cuellar A, Lerma-Díaz JM, Jave-SuárezLF,Aguilar-Lemarroy A,Domínguez-RodríguezJR, González-Ramella O, De Célis R, Gómez-Lomelí $\mathrm{P}$ and Hernández-Flores G: Sensitization of U937 leukemia cells to doxorubicin by the MG132 proteasome inhibitor induces an increase in apoptosis by suppressing NF-kappa B and mitochondrial membrane potential loss. Cancer Cell Int 14: 1475 , 2014.

46. Ding WX, Ni HM, Chen X, Yu J, Zhang L and Yin XM: A coordinated action of Bax, PUMA, and 553 promotes MG132-induced mitochondria activation and apoptosis in colon cancer cells. Mol Cancer Ther 6: 1062-1069. 2007.

47. Ustundag Y, Bronk SF and Gores GJ: Proteasome inhibition-induces endoplasmic reticulum dysfunctin and cell death of human cholangiocarcinoma cells. World J Gastroenterol 13: 851-857, 2007.

48. Wang F, Zhang ZF, He YR, Wu HY and Wei SS: Effects of dipeptidyl peptidase- 4 inhibitors on transforming growth factor- $\beta 1$ signal transduction pathways in the ovarian fibrosis of polycystic ovary syndrome rats. J Obstet Gynaecol Res 4: 2018.

49. Sun Q, Wang Y, Zhang J and Lu J: ENMD-1068 inhibits liver fibrosis through attenuation of TGF- $\beta 1 / \mathrm{Smad} 2 / 3$ signaling in mice. Sci Rep 7: 5498, 2017.

50. Hu ZC, Shi F, Liu P, Zhang J, Guo D, Cao XL, Chen CF, Qu SQ, Zhu JY and Tang B: TIEG1 represses smad7-mediated activation of TGF- $\beta 1 /$ Smad signaling in keloid pathogenesis. J Invest Dermatol 137: 1051-1059, 2017.

51. Zulato E, Favaretto F, Veronese C, Campanaro S, Marshall JD, Romano S, Cabrelle A, Collin GB, Zavan B, Belloni AS, et al: ALMS1-deficient fibroblasts over-express extra-cellular matrix components, display cell cycle delay and are resistant to apoptosis. PLoS One 6: e19081, 2011.

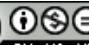

This work is licensed under a Creative Commons Attribution-NonCommercial-NoDerivatives 4.0 International (CC BY-NC-ND 4.0) License. 